\title{
Retinal detachment surgery with silicone oil injection in transconjunctival sutureless 23-gauge vitrectomy
}

\author{
Cirurgia de descolamento de retina com injeção de óleo de silicone no sistema \\ de vitrectomia transconjuntival sem sutura de 23-gauge
}

\author{
Rubens Camargosiqueira ${ }^{1}$ \\ Aline Degasperi Cote Gil ${ }^{2}$ \\ Rodrigo Jorg' $\mathbf{e}^{3}$
}

Trabalho realizado na Faculdade de Medicina de Catanduva e Faculdade de Medicina da Universidade de São Paulo USP - Ribeirão Preto (SP) - Brasil.

${ }^{1}$ Doutor em Oftalmologia pela Universidade de São Paulo USP - Ribeirão Preto (SP) - Brasil; Responsável pelo Departamento de Oftalmologia da Faculdade de Medicina de Catanduva - Catanduva (SP) - Brasil; Médico colaborador em pesquisa do Departamento de Retina da Universidade de São Paulo - USP - Ribeirão Preto (SP) - Brasil; Responsável pelo Centro Especializado Retina e Vítreo do Hospital do Olho de São José do Rio Preto - HORP - São José do Rio Preto (SP) - Brasil.

${ }^{2}$ Fellow do Centro Especializado Retina e Vítreo do HORP - São José do Rio Preto (SP) - Brasil.

Responsável pelo Departamento de Retina e Vítreo da USP - Ribeirão Preto (SP) - Brasil; Doutor em Oftalmologia pela Universidade de São Paulo - USP - Ribeirão Preto (SP) - Brasil.

Corresponding author: Rubens Camargo Siqueira. Av. José Munia, 4500 - São José do Rio Preto (SP)

Zip Code 15090-500

E-mail: rubenssiqueira@terra.com.br

Recebido para publicação em 24.09.2006

Última versão recebida em 13.06.2007

Aprovação em 22.08.2007

Nota Editorial: Depois de concluída a análise do artigo sob sigilo editorial e com a anuência do Dr. Cláudio Renato Garcia sobre a divulgação de seu nome como revisor, agradecemos sua participação neste processo.

\begin{tabular}{l} 
ABSTRACT \\
\hline Purpose: To report a surgical technique for retinal detachment surgery \\
using transconjunctival sutureless 23-gauge vitrectomy with silicone oil \\
injection. Methods: Thirty-one patients with retinal detachment underwent \\
vitreoretinal surgery using a transconjunctival sutureless 23-gauge vi- \\
trectomy system. At the end of the procedure silicone oil was injected into \\
all eyes through a microcannula. After removing the microcannula, a \\
bipolar cautery was used in the conjunctiva over the wound to prevent \\
silicone oil reflux. Results: In all patients retinal reattachment and \\
injection of silicone oil through transconjunctival sutureless 23 -gauge \\
vitrectomy system was possible. Retinal re-detachment occurred in 8 \\
patients (25.80\%) who were submitted to a new vitreoretinal surgery by \\
the technique described above, however, more extensive retinotomy was \\
necessary in all cases, specially inferiorly. Three patients (9.67\%) pre- \\
sented silicone oil leakage in subconjuntival compartment. Another \\
surgical procedure was necessary to remove the subconjuntival silicone \\
oil. Conclusions: The retinaldetachment surgery with silicone oil injection \\
in transconjunctival sutureless 23 -gauge vitrectomy is a safe and efficient \\
technique to repair retinal detachment and it has the advantage of being \\
minimally invasive.
\end{tabular}

Keywords: Retinal detachment/surgery; Vitrectomy; Ophthalmologic surgical procedures/ methods; Silicone oils/therapeutic use; Surgical procedures, minimally invasive

\section{INTRODUCTION}

One of the most innovative vitreoretinal surgical techniques introduced in recent years is transconjunctival sutureless vitrectomy ${ }^{(1-2)}$. In this procedure, three polyamide microcannulae are inserted transconjunctivally through the sclera in pars plana. The vitreoretinal instruments and infusion line are then introduced through these cannulas into the vitreous cavity. Because a thin 25-gauge instrumentarium is used, the small incisions left in the sclera after removal of the cannulas are self-sealing without suturing.

The procedure quickly gathered many advocates. It causes no surgical trauma to the conjunctiva, requires no scleral suture (and thus leaves no postoperative suture-related astigmatism), and entails a distinctly reduced rehabilitation time. Many vitreoretinal surgeons, however, reject the method at all or accept it only for special indications ${ }^{(3)}$. One of the most frequent objections is that the 25-gauge instruments are too flexible for many of the complicated tasks performed on the retina and vitreous body ${ }^{(4)}$. 
Eckardt introduced transconjunctival sutureless 23-gauge vitrectomy. He used this technique in patients with macular pucker, macular hole, proliferative or non-proliferative diabetic retinopathy, rhegmatogenous retinal detachment and central retinal vein occlusion. In some eyes the author used gas tamponade at the end of surgery but not silicone oil ${ }^{(5)}$.

A method for retinal detachment surgery with silicone oil injection in transconjunctival sutureless 23-gauge vitrectomy is presented.

\section{METHODS}

Thirty-one patients with rhegmatogenous retinal detachment in different stages due to proliferatative vitreoretinopathy (PVR) were submitted to three-port pars plana vitrectomy using transconjunctival sutureless 23-gauge vitrectomy system (DORC, Zuidland, Holland). Surgeries were performed under peribulbar anesthesia by the same surgeon (RCS).

The procedure starts by pushing the conjunctiva $1 \mathrm{~mm}$ to 2 mm laterally (i.e., parallel to the corneal limbus) in the inferotemporal, superotemporal, and superonasal quadrants using a special pressure plate to hold it firmly to the sclera. A 23-gauge stiletto blade ( $45^{\circ}$ angle; BD Medical-Ophthalmic Systems, Franklin Lakes, NJ) is then inserted at a $30^{\circ}$ to $40^{\circ}$ angle through the conjunctiva, sclera, and pars plana $(3.5 \mathrm{~mm}$ from the corneoscleral limbus). To obtain scleral tunnels parallel to the corneoscleral limbus, the scleral incisions are made parallel to the corneoscleral limbus. The incision with the 23-gauge stiletto blade is $0.72 \mathrm{~mm}$ wide. Constant pressure is applied to the pressure plate while the incision is made and during withdrawal of the stiletto blade to prevent slippage of the conjunctiva against the sclera ${ }^{(5)}$.

The microcannula is then inserted through the conjunctival incision and into the scleral tunnel using a specially designed blunt inserter.

The pneumatic vitreous cutter was attached to the vitrectomy unit (ACCURS vitrectomy machine -Alcon, Fort Worth, Texas, USA). A cutting rate of up to 1200 per minute and suction of up to $500 \mathrm{mmHg}$ were used.

Limited core vitrectomy and removal of the vitreous close to the sclerotomy used for the insertion of the vitreous cutter were initially performed. In phakic eyes, vitrectomy at the vitreous base from the 6- to 12-o'clock position was performed with the vitreous cutter held with the right hand, and that from the 12- to 6-o'clock position was performed with the left hand.

Initially, the central vitreous was removed (core vitrectomy), with latter peeling of dense epiretinal membranes. Vitreous shaving was performed with scleral indentation by an assistant using a muscle hook. The remaining traction points like star folds with intraretinal fibrosis were identified; and a puncture retinotomy was performed using endo- diathermy, instead of removing membranes with the use of forceps. After relaxing the traction areas, subretinal fluid was aspirated with a long extensible silicone-tipped cannula, taking advantage of the retinotomy created. The entire retina was checked with indirect ophthalmoscopy and, if not attached, additional retinotomies were made to release the traction followed by aspiration of subretinal fluid until retina got flattened against the retinal pigment epithelium (RPE).

Breaks as well as its predisposing lesions were treated with argon laser endophotocoagulation. At the end of the procedure silicone oil was injected into 9 eyes through of the infusion line (Figure 1); 7 eyes through of the second infusion line connected to the microcanula using other microcannula for infusion line (Figure 2) and 15 eyes through of the Alcon silicone injection system (Figure 3). The infusion line was hold firmly with forceps to prevent the line escape during the silicone oil infusion. After withdraw of the microcannula we used the bipolar cautery in the conjunctiva over the wound to prevent any leakage of the silicone oil (Figure 4).

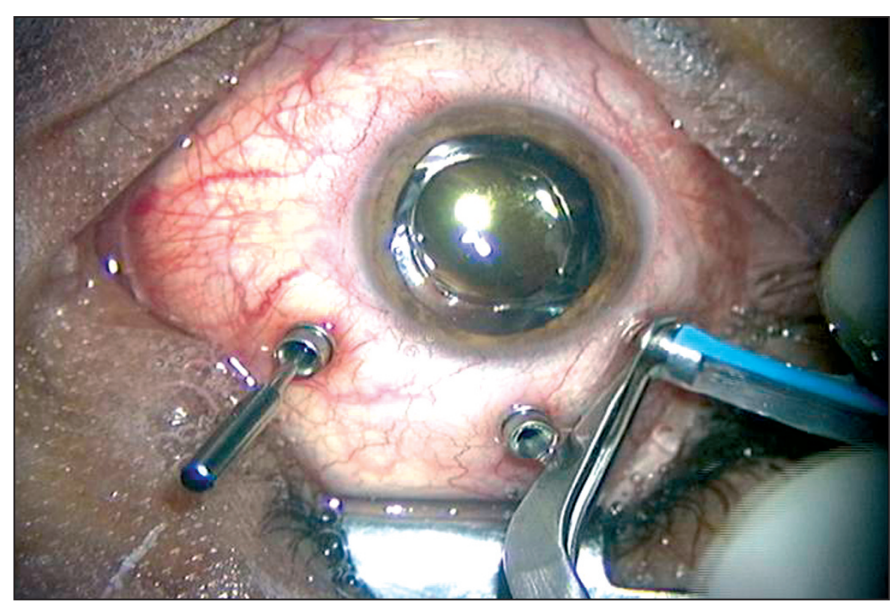

Figure 1 - Silicone oil injected through the infusion line

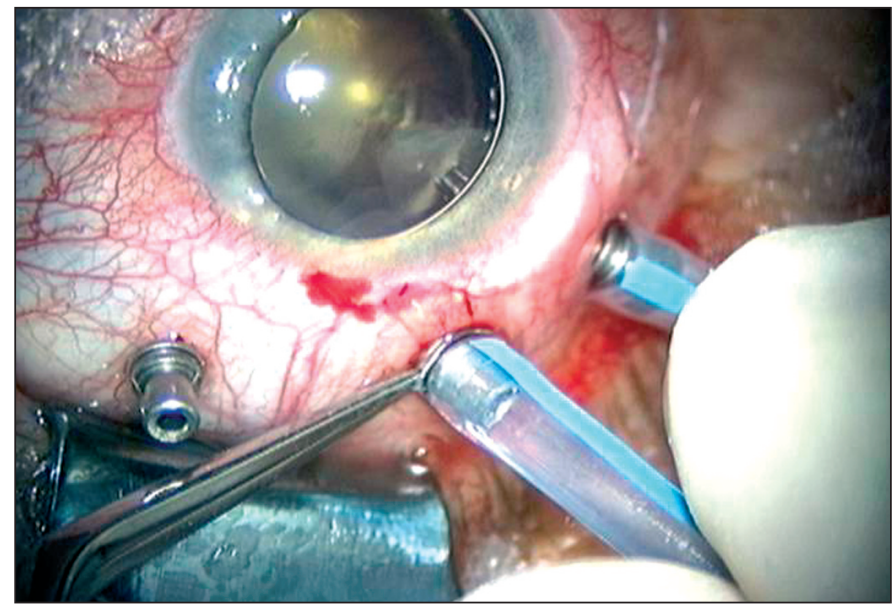

Figure 2 - Silicone oil injected through the second infusion line connected to the microcanula; another microcannula is used for infusion line 


\section{RESULTS}

Thirty-one eyes of 31 patients with retinal detachment with proliferative vitreoretinopathy (PVR) at different stages were submitted to vitreoretinal surgery using high pressure air infusion and puncture retinotomies to relax the points of traction caused by PVR. In the total group 17 patients were males $(54.84 \%)$ and 14 females $(45.16 \%)$; the age range was $15-85$ years (mean age of 53.70). The outcomes are shown on table 1. It was possible to reattach the retina and inject silicone oil in all patients enrolled in the study. Retinal re-detachment occurred in 8 patients $(25.80 \%)$. These patients were submitted to a new vitreoretinal surgery with the same technique initially described; however, more extensive retinotomies were necessary in all cases, mainly inferiorly.

The use of cannulas was free of complications in all cases; there were no cannula-induced lesions of the posterior capsule in phakic or pseudophakic eyes.

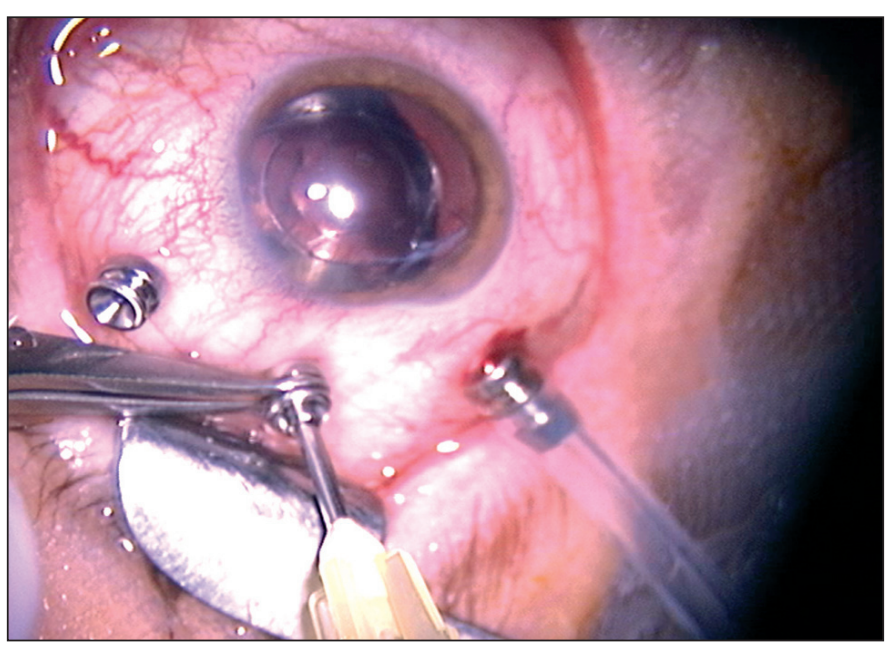

Figure 3 - Silicone oil injected through the Alcon silicone injection system

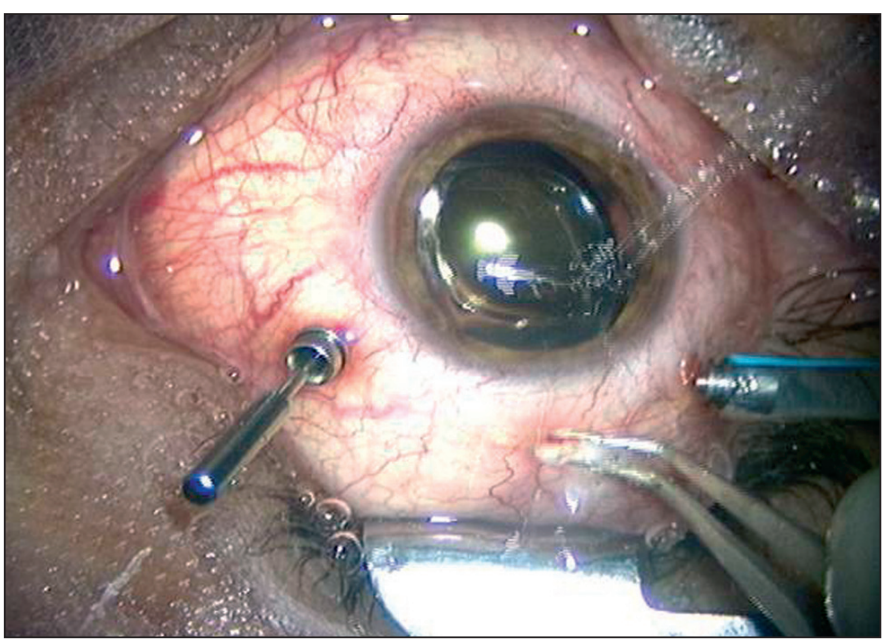

Figure 4 - Bipolar cautery in the conjunctiva over the wound, prevent the little leakage of the silicone oil
In the first patient the infusion line disconnected of the microtrocar during oil infusion and it required reconnection. Therefore the infusion line fixation using forceps was necessary to prevent line escape.

Postoperative wound leaks occurred in three eyes with silicone oil draining into the subconjuntival space (Figure 5). Another surgical procedure to remove the subconjuntival silicone was needed.

Sutures were not used in any case to close the conjunctival or scleral incisions. At follow-up examination, the intraocular pressure (measured with Haag-Streit Goldmann applanation tonometry) varied from 8 to $62 \mathrm{mmHg}$ (mean= $18.32 \mathrm{mmHg}$ ).

Approximately three months after surgery all patients were submitted to silicone oil removal using the 23-gauge system. Suction was performed through the second line infusion (Figure 2) with active aspiration.

\section{DISCUSSION}

This study was designed to retrospectively revise safety data, including visual acuity, incidence of re-detachment, silicone oil leakage as well as the need to use suture due to silicone oil draining to the subconjuntival space. The efficacy of the system was evaluated by comparing preoperative and postoperative VA results and evaluating its efficiency.

Sutureless self-sealing sclerotomies for pars plana vitrectomy were first described by $\mathrm{Chen}^{(6)}$, in 1996, and since then other researchers reported their experience with the technique and its modifications ${ }^{(7-12)}$. Instead of the usual right-angled incision through the sclera, a tunnel-like tangential incision is made at a $30^{\circ}$ to $45^{\circ}$ angle through the sclera. Suture closure is not required because the wound borders are pressed together by the intraocular pressure. The tunnels can be made in the posterior-anterior direction (i.e., in the direction to the corneoscleral limbus) ${ }^{(6-7)}$ in the anterior-posterior direction ${ }^{(8)}$, or

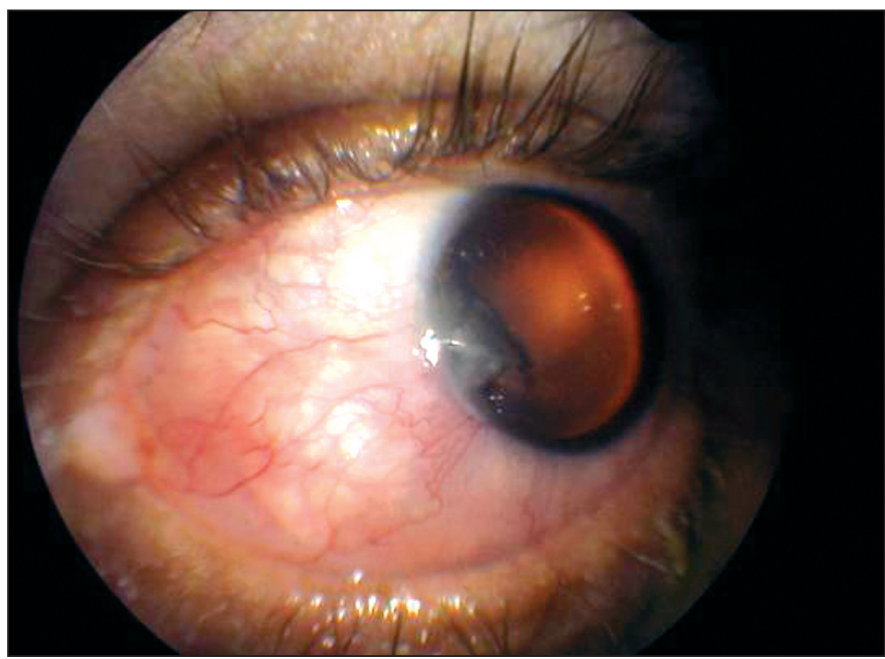

Figure 5 - Silicone oil leakage in subconjuntival compartment 


\begin{tabular}{|c|c|c|c|c|c|c|c|c|c|c|c|}
\hline 1 & 32 & M & $\mathrm{RD}$ after trauma $+\mathrm{VH}$ & $\mathrm{HM}$ & $20 / 80$ & 15 & 13 & No & No & Pseudophakic & 6 \\
\hline 2 & 38 & $\mathrm{~F}$ & $\mathrm{RD}+$ macula OFF + PVR C1 & $\mathrm{CF}$ & $20 / 60$ & 15 & 16 & No & No & Phakic & 2 \\
\hline 3 & 43 & M & $R D+P V R$ C1 & $\mathrm{CF}$ & $20 / 150$ & 16 & 50 & No & Yes & Phakic & 6 \\
\hline 6 & 69 & $M$ & $R D+P V R B$ & $20 / 200$ & CF & 12 & 10 & No & No & Aphakic & 4 \\
\hline 7 & 67 & $\mathrm{~F}$ & $\mathrm{RD}+\mathrm{VH}+\mathrm{SUB}-\mathrm{H}$ & $\mathrm{HM}$ & $\mathrm{CF}$ & 14 & 16 & No & No & Phakic & 7 \\
\hline 8 & 51 & M & $R D+P V R B$ & $20 / 50$ & $20 / 30$ & 15 & 19 & No & No & Pseudophakic & 5 \\
\hline 9 & 15 & $\mathrm{~F}$ & $R D+P V R B$ & $20 / 25$ & $20 / 200$ & 13 & 16 & No & Yes & Phakic & 5 \\
\hline 10 & 26 & M & $R D+P V R C 1$ & $20 / 200$ & $20 / 70$ & 13 & 11 & No & No & Phakic & 4 \\
\hline 11 & 69 & $\mathrm{~F}$ & Partial RD + VH & $20 / 80$ & $20 / 25$ & 17 & 13 & No & No & Phakic & 5 \\
\hline 15 & 51 & M & RD with macula on+ PVR B & $20 / 20$ & CF & 19 & 18 & No & Yes & Phakic & 5 \\
\hline 16 & 61 & M & $\mathrm{RD}+\mathrm{PVR} \mathrm{C} 3$ & $\mathrm{CF}$ & $20 / 200$ & 19 & 17 & No & No & Phakic & 5 \\
\hline 17 & 85 & M & RD + PVR D1 & $C D$ & $\mathrm{CF}$ & 15 & 14 & No & No & Pseudophakic & 6 \\
\hline 18 & 47 & $\mathrm{~F}$ & $\mathrm{RD}+\mathrm{PVR} \mathrm{C} 3$ & HM & $20 / 300$ & 13 & 10 & No & Yes & Phakic & 10 \\
\hline 19 & 27 & $\mathrm{~F}$ & RD + PVR D1 & $\mathrm{HM}$ & $\mathrm{HM}$ & 4 & 8 & Yes & No & Phakic & 5 \\
\hline 20 & 58 & $\mathrm{~F}$ & $\mathrm{RD}+\mathrm{VH}$ & CF & $20 / 200$ & 14 & 36 & No & No & Phakic & 5 \\
\hline 21 & 63 & M & RD + PVR B & $\mathrm{HM}$ & $\mathrm{CF}$ & 8 & 12 & Yes & No & Pseudophakic & 5 \\
\hline 22 & 67 & $\mathrm{~F}$ & RD + PVR D1 & $\mathrm{HM}$ & $20 / 300$ & 13 & 15 & No & No & Aphakic & 6 \\
\hline 23 & 62 & $M$ & $\mathrm{RD}+\mathrm{PVR} \mathrm{C2}$ & $\mathrm{HM}$ & $20 / 200$ & 11 & 14 & Yes & Yes & Lens luxation & 5 \\
\hline 24 & 54 & $M$ & $R D+P V R C 3$ & $\mathrm{CF}$ & $20 / 200$ & 10 & 30 & No & No & Phakic & 4 \\
\hline 25 & 50 & M & RD + PVR D1 & $\mathrm{CF}$ & $\mathrm{HM}$ & 17 & 10 & No & Yes & Pseudophakic & 4 \\
\hline 26 & 54 & M & $R D+P V R D 2$ & $\mathrm{CF}$ & LP & 12 & 62 & No & No & Phakic & 7 \\
\hline
\end{tabular}

parallel to the corneoscleral limbus ${ }^{(7,11)}$. We performed parallel incisions in all cases. Unlike conventional sclerotomies, which are always accompanied by temporary postoperative astigmatism secondary to suture closure ${ }^{(5)}$, tunnel incisions rarely results in astigmatism and lead only to a slight postoperative inflammatory reaction.

Although the conjunctiva is always opened in most sutureless self-sealing sclerotomy techniques, transconjunctival vitrectomy requires merely pin points for microcannulas ${ }^{(3,5)}$. Sclerotomies in 25 -gauge vitrectomy require no suturing because they are only $0.5 \mathrm{~mm}$ in diameter as compared to $1.15-\mathrm{mm}$ width of the sclerotomies in conventional 20 gauge vitrectomy. If 23-gauge instruments are used in combination with microcannulas, the sclerotomies are too large to allow perpendicular scleral incisions without suture closure $^{(1-3,5)}$.

The cannulas can be placed in tunnel incisions $(0.72 \mathrm{~mm}$ wide) running tangentially to the scleral surface ${ }^{(5)}$. In preli- minary investigations on eyes from eye banks, we first used a beveled trocar ${ }^{(1,4)}$. However, the trocar did not cut well enough to make a tunnel incision and we used a stiletto blade. The cannulas were then inserted into the tunnel with the aid of a special blunt inserter and remained firmly in place in all eyes, even during the whole procedure requiring extensive vitrectomy on the retinal periphery under circular scleral indentation. In a few eyes, a slight accumulation of infusion liquid drained from under the conjunctiva when the cannulas were withdrawn at the end of the surgery ${ }^{(1-2,4)}$.

We reported retinal detachment surgery with silicone oil injection in transconjunctival sutureless 23 -gauge vitrectomy. In all patients it was possible to reattach the retina and inject silicone oil through the transconjunctival sutureless 23-gauge vitrectomy system.

Postoperative wound leaks have always created the greatest concern about sutureless 25-gauge technology. Wound leaks can lead to hypotony resulting in choroidal detachments, ble- 
eding, need for vitreous volume enhancement, or re-operations to suture the wounds. Intraoperative wound leaks through the cannula can result in bleeding, vitreous prolapse with secondary vitreoretinal traction, miosis due to hypotony, or even retinal prolapse $^{(4)}$. We used bipolar cautery in the conjunctiva over the wound to prevent any leakage of silicone oil. However, three cases presented silicone oil leakage in subconjuntival space without other complications (choroidal detachments or bleeding) and a new procedure was necessary for remove the subconjuntival silicone and to suture the wounds.

In conclusion, the retinal detachment surgery with silicone oil injection in transconjunctival sutureless 23-gauge vitrectomy is a safe and efficient technique to repair retinal detachment and offers a special advantage of being minimally invasive.

\section{RESUMO}

Objetivos: Relatar técnica cirúrgica para descolamento de retina utilizando sistema de 23-gauge com injeção de óleo de silicone. Métodos: Trinta e um pacientes com descolamento da retina foram submetidos a cirurgia vitreorretiniana usando o sistema 23-gauge de vitrectomia transconjuntival sem sutura. Ao final do procedimento o óleo de silicone foi injetado em todos os olhos através de uma microcânula. Após a retirada da microcânula, foi utilizado cautério bipolar na incisão conjuntival para prevenir o vazamento do óleo de silicone. Resultados: Em todos os pacientes foi possível reaplicar a retina e injetar o óleo de silicone através do sistema 23-gauge de vitrectomia transconjuntival. Redescolamento da retina ocorreu em 8 pacientes $(25,80 \%)$ os quais foram submetidos a uma nova cirurgia vitreorretiniana com a mesma técnica, entretanto, uma retinotomia mais extensa foi necessária em todos estes casos especialmente na parte inferior que foi mais comprometido. Em 3 casos $(9,67 \%)$ houve extravasamento do óleo de silicone para o compartimento subconjuntival. Novo procedimento foi necessário para remover o silicone subconjuntival. Conclusões: A cirurgia do descolamento da reti- na com injeção de óleo de silicone utilizando o sistema 23gauge de vitrectomia transconjuntival é uma técnica segura e eficiente para o reparo do descolamento da retina e oferece a vantagem de ser um sistema minimamente invasivo.

Descritores: Descolamento retiniano/cirurgia; Vitrectomia; Procedimentos cirúrgicos oftalmológicos/métodos; Óleo de silicone/uso terapêutico; Procedimentos cirúrgicos minimamente invasivos

\section{REFERENCES}

1. Fujii GY, De Juan E Jr, Humayun MS, Pieramici DJ, Chang TS, Awh C, et al. A new 25-gauge instrument system for transconjunctival sutureless vitrectomy surgery. Ophthalmology. 2002;109(10):1807-12; discussion 1813. Erratum in: Ophthalmology. 2003;110(1):9. Comment in: Ophthalmology. 2003;110(1):9

2. Fujii GY, de Juan E Jr, Humayun MS, Chang TS, Pieramici DJ, Barnes A, Kent D. Initial experience using the transconjunctival sutureless vitrectomy system for vitreoretinal surgery. Ophthalmology. 2002;109(10):1814-20. Comment in: Ophthalmology. 2003;110(12):2427-8; author reply 2428. Ophthalmology. 2003;110(12):2427; author reply 2427. Ophthalmology. 2003;110(12):2428-9; author reply 2429.

3. Packo K. Early experience reveals benefits of 25-Ga. Technology. Rev Ophthalmol [serial on the Internet]. 2004; [cited 2006 Dec 12] 11: [about 8 p.] Available from: http://www.revophth.com/index.asp?page=1_563.htm

4. Charles S, Calzada J, Wood B. Vitreous microsurgery. 4th ed. Philadelphia. Lippincott Williams \& Wilkins; 2006. p.85-94

5. Eckardt C. Transconjunctival sutureless 23-gauge vitrectomy. Retina. 2005; 25(2):208-11.

6. Chen JC. Sutureless pars plana vitrectomy through self-sealing sclerotomies. Arch Ophthalmol. 1996;114(10):1273-5.

7. Kwok AK, Tham CC, Lam DS, Li M, Chen JC. Modified sutureless sclerotomies in pars plana vitrectomy. Am J Ophthalmol. 1999;127(6):731-3.

8. Assi AC, Scott RA, Charteris DG. Reversed self-sealing pars plana sclerotomies. Retina. 2000;20(6):689-92.

9. Jackson T. Modified sutureless sclerotomies in pars plana vitrectomy. Am J Ophthalmol. 2000;129(1):116-7.

10. Rahman R, Rosen PH, Riddell C, Towler H. Self-sealing sclerotomies for sutureless pars plana vitrectomy. Ophthalmic Surg Lasers. 2000;31(6):462-6.

11. Theelen T, Verbeek AM, Tilanus MA, van den Biesen PR. A novel technique for self-sealing, wedge-shaped pars plana sclerotomies and its features in ultrasound biomicroscopy and clinical outcome. Am J Ophthalmol. 2003; 136(6):1085-92.

12. Eckert T, Eckardt C. Verhalten des Hornhautastigmatismus nach Pars-planaVitrektomie mit oder ohne gleichzeitiger Kataraktoperation. Ophthalmologe. 1996;93(1):38-44. 